Red State 
Number Forty-Two

Jack and Doris Smothers Series in Texas History, Life, and Culture 


\section{Red State}

An Insider's Story of How the GOP Came to Dominate Texas Politics

WAYNE THORBURN

University of Texas Press 
Publication of this work was made possible in part by support from the J. E. Smothers, Sr., Memorial Foundation and the National Endowment for the Humanities.

Copyright (C) 2014 by the University of Texas Press

All rights reserved

Printed in the United States of America

First edition, 2014

Requests for permission to reproduce material from this work should be sent to: Permissions

University of Texas Press

P.O. Box 7819

Austin, TX 78713-7819

http://utpress.utexas.edu/index.php/rp-form

(a) The paper used in this book meets the minimum requirements of ANSI/NISO Z39.48-1992 (R1997) (Permanence of Paper).

\section{Library of Congress Cataloging-in-Publication Data}

Thorburn, Wayne J. (Wayne Jacob), 1944-

Red state : an insider's story of how the GOP came to dominate Texas politics / Wayne Thorburn. - First edition.

pages $\quad \mathrm{cm} .-$ (Jack and Doris Smothers series in Texas history, life, and culture ; Number Forty-Two)

Includes bibliographical references and index.

ISBN 978-0-292-75920-6 (cloth : alk. paper)

1. Texas - Politics and government-1951- 2. Republican Party (Tex.) - History.

3. Democratic Party (Tex.) - History. 4. Political parties-Texas-History.

5. Party affiliation-Texas-History. 6. Political culture-Texas. I. Title. JK4816.T56 2014

$324.09764^{\prime} 09045-\mathrm{dc} 23$

2013046760

doi:10.7560/759206 